\title{
Public policies creating tensions in Montado management models: Insights from farmers' representations
}

\author{
Teresa Pinto-Correia*, Carla Azeda \\ ICAAM - Instituto de Ciências Agrárias e Ambientais Mediterrânicas, Universidade de Évora, Pólo da Mitra, Ap. 94, 7002-554 Évora, Portugal
}

\section{A R T I C L E I N F O}

\section{Article history:}

Received 25 February 2016

Received in revised form 19 February 2017

Accepted 22 February 2017

Available online 1 March 2017

\section{Keywords:}

Montado

Management

Decay

Representations

Farmers

Conflicts

\begin{abstract}
A B S T R A C T
The Montado is the silvo-pastoral land use system dominant in Southern Portugal, and similar to the Dehesa in Southern Spain. These systems combine an open tree cover of cork and holm oaks with grazing in the under-cover. Despite the acknowledged value of these systems due to their adaptation to the scarcity biophysical conditions of Southern Iberia, the uniqueness of cork production, the biodiversity values and the support of multiple public goods and services, in Portugal the area of the Montado is declining every year. It has been shown before how this decline is related to increased grazing pressure and use of inadequate soil mobilization techniques. Supported on social sciences theoretical insights, this paper focus on the farmers decision process, and the representations that support their decisions. The analysis is grounded on a large scale survey followed by in-depth interviews to Montado farmers. The results show that there is an underlying conflict between farmers representation of the Montado and the practices they are applying in their everyday management. Dominant representations of the Montado by farmers rely strongly on the tree cover and the forestry component of the system. While their management is strongly focused on the livestock and grazing resources. Farmers are abandoning a resilient thinking of their farm system considering the factors internal to the system, to adapt an external, driver oriented representation of their farm system. CAP coupled payments are seen as the main cause of this change. If the policy construction remains in its present state, the resilience of the Montado as a complex socio-ecological system is threatened in the very short term.
\end{abstract}

(c) 2017 Elsevier Ltd. All rights reserved.

\section{Introduction}

The Montado is the silvo-pastoral system dominant in the landscape of southern Portugal, and equivalent to the Dehesa in southern Spain. These land use systems occupy approximately $1 \mathrm{M}$ hectares in Portugal and $3 \mathrm{M}$ hectares in Spain, constituting the paradigmatic land use systems and landscapes of southern Iberia (Aronson et al., 2009; Ferraz-de-Oliveira et al., 2016; Pinto-Correia, 1993; Pinto-Correia et al., 2011). In the Montado, there is a tree cover dominated by evergreen oaks, mostly cork oak (Quercus suber L., 1753) in varying densities, and pastures in the undercover. These may be natural or improved pastures, and often there is dispersed shrub or patches of shrub in the most non-accessible patches. The livestock feed on the pastures and also profit from the masts and acorns, as well as the young tree shoots. In the dry season, livestock fodder may also be produced in other, more open plots in the farm. In a balanced Montado, the grazing pressure is such that the

\footnotetext{
* Corresponding author.

E-mail address: mtpc@uevora.pt (T. Pinto-Correia).
}

encroaching shrub is avoided and natural regeneration of the trees is possible.

Despite its adaptation to the scarce natural resources and variability of the climate, its acknowledged qualities as a High Nature Value farming system, a highly attractive landscape, and a regional identity fundament, these systems are nevertheless in decay. Recent studies have shown that the Montado's total extension has reduced in the last 25 years, with 5000 ha lost on average per year (Costa et al., 2011; Godinho et al., 2014, 2016). This decrease is not primarily due to cuts in the tree cover or replacement of the silvo-pastoral system by another land use system. It is caused by a progressive decline in the tree cover and a reduction in natural tree regeneration, and thus a reduction in tree density, which in turn leads to larger and larger openings in the Montado land cover (Almeida et al., 2013; Godinho et al., 2014, 2016). When the trees are missing or in too low density, there is an open grazing or shrub area, but the complementarity between grazing activities and the tree layer is lost, and the Montado has been dismantled as a silvo-pastoral system. Consequently, it is difficult to maintain the recovery of the tree cover, which traditionally regenerated by natural replacement of the old trees by young shoots 
(Acácio and Holmgren, 2012). Without the tree cover there is no Montado and the constraints imposed by the natural environment are a strong limiting factor for other regeneration actions or for other uses. As it has been proved in other situations throughout the world, the degradation of forest ecosystems due to tree cover loss and fragmentation has long-lasting and negative environmental consequences, such as species extinction, water and soil quality degradation, and invasive species, and is therefore a subject of upmost concern in terms of public policy (Hartel and Plieninger 2014; Liu et al., 2016).

Previous studies have shown how the trend towards an intensification and specialization of livestock production in the Montado is closely related to the decay of the tree canopy in the grazing areas, and thus the decline of the system (Godinho et al., 2014, 2016; Moreno et al., 2014). Even if other factors also played a role, the Common Agricultural Policy (CAP) and its specific application to Portugal have been seen as the main driver for this intensification in the last two decades: livestock payments have remained coupled to the total number of animals and cattle payments have progressively increased while sheep payments are kept rather low (Almeida et al., 2013; Guerra et al., 2015; Guerra et al., 2014). There are thus different and simultaneous changes which contribute to increased pressures on the tree cover and on the grazing resources in the Montado: replacement of sheep by cattle, replacement of light indigenous breeds of cattle by heavier breeds, increase in the number of cattle heads, and shrub control practices using heavy machinery. While the former lead to exhaustion of the natural pastures, disappearance of the young tree shoots, damage to the young trees, and soil compaction, the latter affects the system as it leads mainly to severe damage to the tree root system. The national discourse within the farming sector, following the specialization paradigm, has contributed towards reinforcing the intensification effect driven by the CAP (Fragoso et al., 2011; Pinto-Correia and Godinho, 2013).

Nevertheless, analyses of the processes of change in land use and landscape sciences tell us that policies and sector orientations do not directly affect the landscape or land use; they affect the farmers, who take decisions that affect and alter said land use and landscape. In order to understand how policies affect the farm and interplay with other factors, the analysis needs to emphasize the role of the farmer (Herzfeld and Jongeneel, 2012). Farmers take decisions according to a complex value system and management strategy. Therefore, the farm systems approach considers the farm as a unit composed of the farmer and his mental models, preferences, goals, abilities, etc., and the physical farm, with a variety of subsystems that include animals, crops, buildings, finances, etc. (Darnhofer et al., 2012; Milestad et al., 2012). The theoretical background developed by social sciences on farm systems helps us to understand the positioning of the farmer, or land manager, in the complex system of his or her farm and dealing with the institutional framework to which he/she is subject (Cochet, 2012; Schermer et al., 2016; Herzfeld and Jongeneel, 2012; Noe et al., 2008). Thus, understanding processes of change in complex land use systems such as the Montado, which ultimately also affect the landscape, requires an in-depth understanding of the farmer's decision-making processes (Darnhofer et al., 2012).

This is what this paper is about. The goal of the paper is to bring forward an analysis of the decision-making process characteristics of Montado landowners today. The paper aims to shed light on the different representations that the landowners have of this system and the existing convergence, but also conflict, between their value set and actions, ultimately constituting a framework for the difficult conservation of a balanced Montado. In order to address these issues, the paper is based on an empirical analysis undertaken in central Alentejo, in the municipality of Montemor-o-Novo, where the Montado still comprises $60 \%$ of the municipality's total utilized agricultural area.

\section{Material and methods}

\subsection{The case-study}

Located in the region of Alentejo (Southern Portugal), with an area of $1,232.1 \mathrm{~km}^{2}$ and a population density of $15.1 \mathrm{hab} / \mathrm{km}^{2}$, the conditions in the municipality of Montemor-o-Novo (Fig. 1) are generally favourable to silvo-pastoral production. The climate is typically Mediterranean, with marked differences between the dry season and the rainy season temperature ranges. However, due to the municipality's location, less than $100 \mathrm{~km}$ from the coastline, there is high precipitation and mild temperatures compared with southern Portugal as a whole. Likewise, there is a predominance of granite mother-rock and relatively deep soils in comparison to the average in Alentejo. Despite the presence of significant rugged surface areas, the landscape is dominated by plains.

As in the whole of Alentejo, the Montado farms are mainly largescale, family-owned estates between 100 and 1000 ha, and in some cases between 50 and 100 ha. The Montado rarely covers the total area of the farm, though it usually covers the largest part - the remaining open pastures - which are also used for the livestock production. Usually, this primary activity is combined with cork and wood production, as well as with annual crops used for forage. As a testament to the high nature value of many of the Montado areas, the municipality land partially falls under two Nature 2000 sites: Cabrela (15\% of the municipality) and Monfurado (13\% of the municipality).

Most frequently, farmers have inherited the farm as direct successors or through marriage. In some cases the land has been bought recently or is leased from the traditional owners. Montemor-o-Novo is the municipality in Portugal with the highest proportion of farmers with a university degree, and also a more favourable demographic distribution than the Portuguese average: $40 \%$ of the farmers are over 65 years old, while at the national level this rate is $52 \%$. This profile of more educated and younger farmers than the national average can be explained by a combination of factors, but the proximity of the metropolitan area of Lisbon $(100 \mathrm{~km})$ surely contributes to the higher capacity of the municipality to attract and maintain younger and well-educated families.

\subsection{Methods}

The analysis is based on in-depth interviews with selected Montado farmers in the municipality of Montemor-o-Novo.

Prior to these interviews, in a first step of the analysis, a detailed survey of the farms' and farmers' characteristics was applied to a representative sample of the farms in the municipality. From a total of 865 farm units in the municipality, 328 have more than 50 ha, and are thus likely to be Montado farms or farms where the Montado land cover is significant. In the first step, 51 of these large farm units, spatially distributed in the whole municipality territory, were surveyed.

The first step survey concerned farm and farmer characteristics, farmer management options and his/her attitudes towards farming, the environment, the market and public policy. A cluster analysis of the results has led to the identification of three types of Montado farmers: 1) productivist livestock farmers (58\%), 2) entrepreneur cattle farmers (35\%), and 3) multifunctional innovative (7\%) (Almeida et al., 2013; Barroso and Pinto-Correia, 2014). The productivist livestock farmers are mainly full-time farmers, highly focused on increasing production and thereby increasing their income, highly determined by the CAP payments of the $1 \mathrm{st}$ 

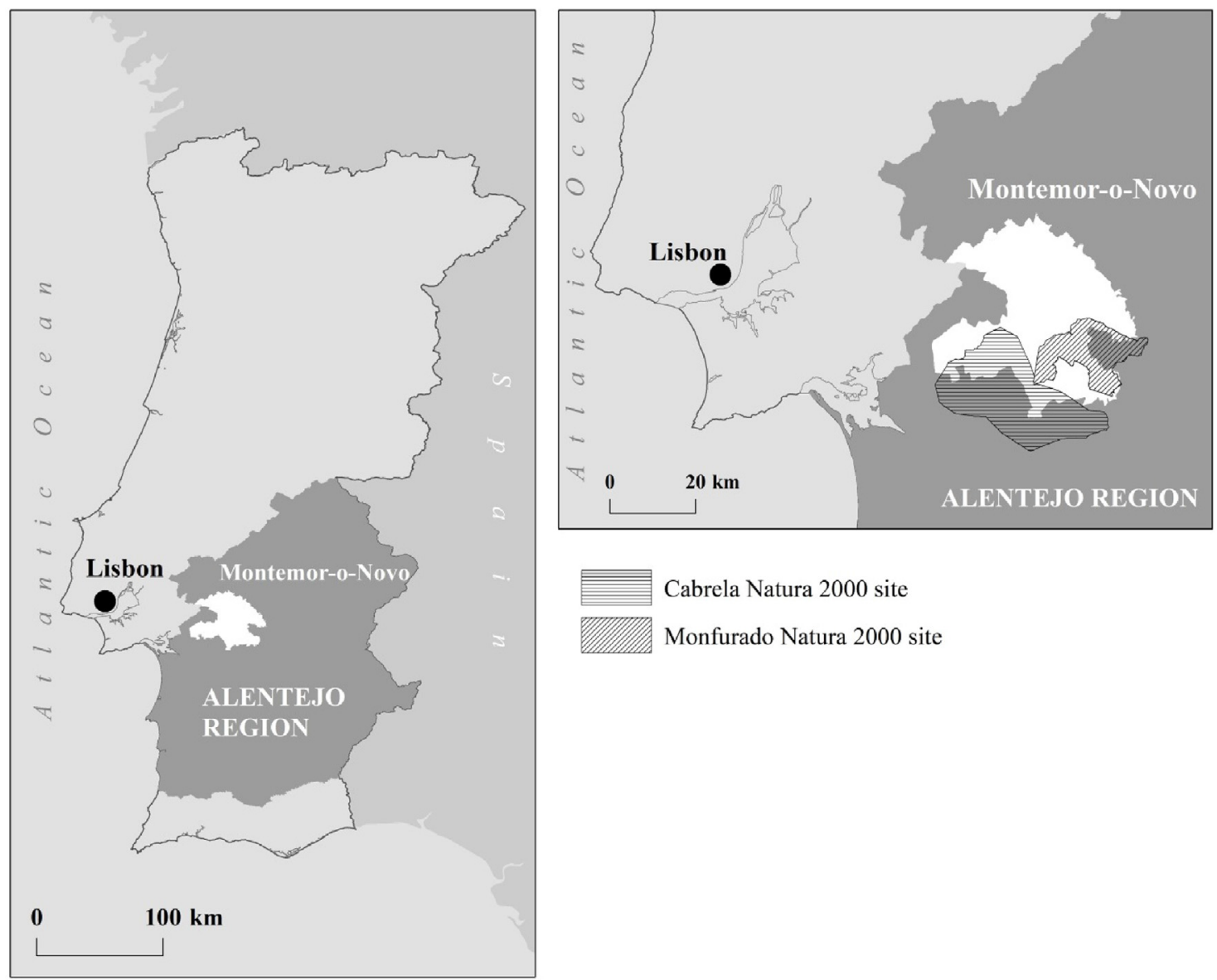

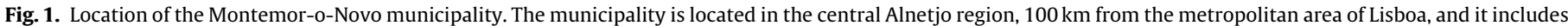
large areas of two Natura 2000 sites: Monfurado and Cabrela.

Pillar. The entrepreneur cattle farmers are also full-time farmers, who introduce innovative practices to the farm, such as converting the extensive cattle production to organics, for example; they receive both 1 st and 2 nd Pillar payments. The multifunctional innovative group may have other jobs besides farming and, in any case, have other income sources. The main income source in the farm is related with other activities, such as hunting or tourism, and cattle production is not the main priority. Many of them receive no payments, or when they do, they are 2nd Pillar payments. Only in the last type, which is by far the least frequent, is the average grazing pressure in the Montado below what previous studies have shown to be associated with the tree cover decline (Godinho et al., 2014, 2016; Almeida et al., 2015).

From those 51 farmers, and following the relative distribution in the typology, 15 farmers were selected for a semi-structured interview in a second step: 8 of type 1), 6 of type 2) and one of type 3 ). Two of these are women, the others are men. Their profile and the farm characteristics were known beforehand from the survey data. The interview addressed questions aiming to understand the farmers' viewpoints: a) opinion regarding the typology produced and its accuracy with respect to themselves and the farmers they know; b) representation of the Montado; c) requirements for the sustainable management of the Montado; d) own management and future perspectives; e) the role of the CAP, present orientations and proposals for required changes.

The farmers have been interviewed in their homes, at their farm or a location they have selected, all by the same interviewer. The interviews lasted between $1 \mathrm{~h} 30$ and $3 \mathrm{~h}$, and were recorded. A full transcription of each interview was made.
The interview's transcriptions have been analyzed following a discourse analysis approach (Antaki 2008; Hyvarinen 2008). Discourse analysis aims to reveal, and sometimes unmask, the personal meaning-making of those being focused on, through the analysis of what is explicitly said but also of what remains unsaid. In the present case, the analysis was based on a careful reading and interpretation of the interview transcriptions, in order to extract the central themes and repertoires in the farmers' discourse, and thus to uncover the underlying dimensions among which the interviewee made sense of his/her experiences and actions. Discourse analysis can be used in different perspectives. Here we used the perspective of considering discourse as a frame of reference: an organized set of social representations, through which people understand, explain and articulate the complex social and physical environment in which they are immersed (Hermans et al., 2012).

Insights from social sciences theory have supported this analysis, as the aim was to look particularly into the social component of farm management and understand farmers' representations, values and motivations, as well as their interaction with their management practices (Godinho et al., 2014, 2016). The actor network theory (ATN) has been particularly supportive, as it emphasizes and considers all surrounding factors - recognizing that no one acts alone. ATN provides the conceptual framework for understanding how farms are organized and how decisions are made, considering the extremely heterogeneous combination of natural, technical, economic and social elements and interactions that compose a farm and its surrounding context (Egon and Alroe 2012). ATN's strength is that it focuses on relationships and provides a general and open understanding of the relational structure of farm systems, tak- 
ing into consideration both internal and external factors (Milestad et al., 2012). In this case, looking at farmers' representations as drivers of their management options, ATN has supported insights into the context and complex interactions, which may influence these representations.

\section{Results: contradictions in farmers' stated values and actions}

With regard to the farmers' typology, the interviewees generally agreed with the types described, and also with the type they were included in. Some said they corresponded to the type in which they were included, but combined with another one. Farmers classified as productivist livestock farmers tend to state that all Montado farmers they know are in the same type, and that intensification is the only way to maintain a Montado farm. However, some found it difficult to place other farmers they know into one single category and claimed that in each farmer's strategy there is an element of each of the three types.

One highly revealing aspect is that the perception of the Montado is very much consensual, with the determining characteristic being the trees. For many, the first reaction to "How would you define the Montado?" was "the Montado is the trees" or "the Montado is trees", or "a forest", "a Mediterranean forest". Some mention the type of trees, cork and holm oaks (Quercus suber and Quercus rotundifolia), as well as cork production. One even says "The Montado is cork". Only a few talk here about the grazing animals, and when they do, they refer to a forest system with multiple associated components, the animals being the Iberian pig or sheep. Five of these farmers also refer to the Montado as heritage, an identity landscape, and an iconic value of Alentejo and even of the country as a whole. But besides these five, others refer here to the societal obligation to maintain the Montado: "we need to keep it, as much as possible, it is our role", or "we all have to preserve it", "we have the obligation to preserve it", "we cannot let it die". The Montado is thus seen as a forest-based system, closely linked to the production of cork and the corresponding income generation, and also as a unique and valuable heritage.

In line with this representation, clearly centred in the trees, the sustainable management of the Montado is clearly defined as management where the maintenance of the trees is a central goal. As one of the farmers expressed, "the crucial factor is to understand the tree", and another: "the goal is to take care of and maintain the trees". Many refer to the need to safeguard the tree cover by avoiding deep ploughing, planting new trees and providing them with water during the initial summers, and also avoiding shrub encroachment, which is seen as competing for resources with the trees. Thus, a clean Montado, with no shrub in the undercover, is associated with a sustainable Montado. Furthermore, the notion of a balanced use of the existing resources, through continuous adaptive management, is much present. Most of those interviewed refer to the need to maintain a balance between the conditions of the Montado, and thus its carrying capacity, and the interventions for pasture improvement, on the one hand, and grazing intensity and breed on the other. A few farmers refer to the need to fertilize and improve the pastures so that more plant material is available for livestock, but also so that the trees are fertilized. Others defend low livestock densities, and generally avoiding cattle, or even managing the trees without livestock. In this last case, such opinion is not in the sense of farm management with no other activity besides the forest; it is more in the sense of setting aside high-quality Montado areas as conservation patches, preserved as forest systems, within larger farm units where most of the area is dedicated to agricultural production, be it livestock grazing or other.
Furthermore, when asked about the sustainable management of the Montado, there are frequent references to unbalanced management strategies, where serious mistakes have been made (excessive grazing pressure or excessively deep ploughing), in the past. Several farmers cite the former lack of knowledge and belief in rationalization and mechanization as the main cause. These are references to a period after the Revolution in the '70s and the consequent cooperative management of many large estates for a few years, followed by the integration of Portugal into the European Union. The previous period, up to the 1970 s, is seen as a period of wise management, where cattle would not be accepted in the Montado, shrub control was mainly undertaken manually and soil ploughing with heavy machinery was still a seldom practice. As for the present, many claim there is a need for much more training and information in order to achieve more sustainable management, but some also claim there is now generally better information and education for farmers, and therefore wiser management today.

Then, when asked about their personal management of the Montado today, the focus is much different. Most replies deal with the livestock: grazing management, the improvement of pastures, livestock composition, feeding requirements and worrying costs linked to the purchase of fodder outside the farm. The dominant livestock is cattle. Only three of the fifteen farmers have only sheep as livestock in their Montado farm. One has sheep for milk, while the other two have sheep for meat. All the remaining farms have cattle, of different breeds, often more than one breed (pure or mixed), and in some cases combined with sheep. One farmer has dairy cows, but also extensive meat cattle in the same farm unit.

The capacity of the pastures to feed the animals is a central concern. The period the livestock remains on the pastures and the need to provide extra fodder at the end of the dry season is the main issue. The capacity to produce this extra fodder in other areas inside the farm, and therefore to be independent from imported fodder, is a general goal. Those who do not have this capacity are concerned about their external dependency and, hence, their vulnerability in the dry years. Therefore, they aim to increase their fodder production capacity, for example by increasing irrigation areas (through pivots). Some of the farmers refer to practices for improving the pastures. Having different paddocks and moving the animals frequently in order to make a better use of the pastures is also mentioned. Yet once again the central concern is the most rational and economical way of feeding the animals, and not tree cover survival. Several farmers mentioned economic rationality and economic sustainability as their management goal, or even as the only possible goal: "environmental sustainability is really wonderful but if there is no economic sustainability then there is no future", or "only when you have another income source and the Montado is managed as an amenity can the balance of the whole system be the priority". In this way, they justify the need to maintain cattle in the Montado: with the present CAP construction and the high coupled payments for cattle, maintaining intensive cattle production is seen as the obvious economic rationality.

Generally, in response to questions about their current management, there is no reference to the tree cover. This discrepancy in relation to the previous statements about the Montado's definition and sustainable management is highly significant. One farmer, who stated that the sustainable management of the Montado relies on the careful understanding of tree behaviour and detailed attention to cork production over time, says of his own management: "cattle is the absolute priority; cork and forestry products are sub-products of the Montado". Sheep producers mention that they choose this type of animal because they like it most or because of expectations of high income (in the case of dairy sheep), but also because of their better adaptation to the maintenance of the tree cover.

Among those who have cattle, only two farmers refer to tree cover maintenance as a central issue. They correspond to the minor- 
ity within the typology produced in the first step of the analysis: multifunctional farmers. They are the one classified as a multifunctional manager and another classified as an entrepreneur cattle farmer who sees himself more as a multifunctional manager. They promote management practices where the balance and renewal of the tree cover is one requirement, both through low grazing densities, the production of fodder inside the farm, and the preservation of Montado areas from cattle grazing.

In fact, these two farmers tend to separate cattle production from the Montado, focusing on other grazing species - sheep and Iberian pigs - in the Montado and keeping the cattle mostly outside or in selected areas, with very low density. Among the remaining cattle producers, some also mention that they keep certain Montado areas clear from grazing or have even planted new trees to increase density. However, these are far from the central management concerns and somehow reveal a trend for considering the Montado to be in good stand and have high tree density, as a residual part of the farm. One farmer, for instance, refers to his plantation of new trees as an expression of his care for the Montado; yet he has planted 40 out of a total of 700 ha.

This reduced reference to the trees is most striking considering that cork production, whose quantity and quality depends directly on the good condition of the tree cover, is in many cases considered as an important income and part of the long-term management strategy of the farm, as expressed in the first step inquiry to these farmers. Cork is only extracted every nine years from each single tree and normally all trees in a farm unit are harvested in one or two different years so that the required work investment and income are gathered. Therefore, the income from cork is significant but not on a regular year basis, and was mentioned in the interviews as covering the needed large investments to continue the farm's livestock production, as well as maintain irrigation infrastructures, buildings and fences.

In relation to the CAP, the judgement is very similar among all farmers: the CAP payments drive the intensification of the Montado and excessive cattle density in the undercover, and are solely responsible for this trend. Those interviewed refer to the CAP influence as a kind of fatality: "the incentive for cattle production is clearly damaging the Montado and a lot of what we are doing is nonsense, but there is no other possibility; as long as cows are profitable, we will continue to have cows"; "if we do not consider what gives us a regular yearly income, then we cannot survive". And the CAP mechanisms are seen as leading the farmers to focus only on income: "a lot of farmers only aim to take the highest income out of the Montado, and therefore they have cows; they do not even like cows or treat them well, they just want to earn money"; "Montado owners know too little and do not know what is best; they live too fas, and need to obtain a lot of money from their farms".

Only a few of the interviewed farmers mention the agrienvironmental schemes as relevant payments for them. For instance, concerning the support for autochthonous cattle breeds, which are lighter and less demanding and therefore less impacting on the Montado, the agri-environmental payment is considered "ridiculous" in relation to the lower income generated by these breeds in the market. The majority of farmers refer solely to the first pillar payments. Asked about how their practices would change if the CAP payments they receive were maintained but not coupled to the cattle heads, the reaction is also quite homogeneous: the cattle density would be substantially reduced and cattle would be progressively replaced by sheep, at least partially. A few farmers defend their current practice by stating they would not change anything in their management. But when asked about what they think would should be changed in the CAP, they clearly refer to a replacement of the present payment mechanisms by others that are more respectful of the whole Montado system and the balance between grazing activities and the tree cover.
It is obvious that, as in most other farm systems in Europe, a significant part of the farms' income is dependent on CAP payments and the system is built with these payments as a structuring factor. This is not unique. But what is particular in the case of the Montado is that all farmers interviewed acknowledge mainly negative impacts resulting from the manner in which the CAP functions and would opt for other practices and products if the schemes were structured differently.

\section{Discussion: farmers in a difficult quandary}

There is a fundamental conflict emerging from the analysis, between the representation the farmers have of the Montado, and their representation of what their own Montado management is about. The representation of the Montado is strongly focused on the tree component, on the Montado system as a forestry system with which cattle grazing is associated. All the interviewees clearly feel that the sustainability of the Montado is centred on the preservation of the trees. Nevertheless, current management is presented as totally centred on livestock management and the economic rationale behind the balance between livestock intensity and fodder availability. The trees seem to have disappeared from the farmers thoughts amid these management concerns. This is the case even though, in the first step enquiry, many mentioned the cork income as a significant part of the economic rationality of the farm. In livestock grazing systems, efficient stock feed management is always critical to a farm's success (Nuthall 2012). In the case of the Montado, with the limited productive capacity of Alentejo soils, together with the characteristic inter-annual fluctuations of the Mediterranean climate, adaptive and efficient livestock management is a crucial factor in avoiding potential overgrazing risks (Sales-Baptista et al., 2015). Such management is complex, naturally raising concerns with respect to farmers' strategy making. But what is striking in the discourse of the farmers interviewed is that the maintenance of the trees is absent from the management description, when it is clearly known by all of them that grazing pressure is affecting both pasture productivity and the trees' stand and regeneration, and when at the same time many of them consider cork to be a significant income source for their farm.

It seems that there is a long-term view, which includes the trees and the overall balance of the system as a forestry system and a producer of cork, often connected with the sense of heritage and identity - the Montado as something valuable that has been passed down and which the farmers have a responsibility to maintain for the future. Then there is a short-term view, which is conveniently separated from the first and in which the central issue is the economic rationality and the need to obtain as much income from the livestock as possible, taking into consideration the constrains of the farm. These two outlooks are in direct conflict with each other. This conflict is hardly acknowledged by the farmers - they reflect on the contradictions and the tensions created yet present them as inevitabilities which are currently out of their control, thereby keeping possible conflict outside their decision-making sphere. In this way, they rationalize the short-term strategy they are following - which is only an economic rationality and only short term, on a yearly basis. The separate references and representations arising from the two sets of questions leads us to formulate the hypothesis that, by separating the two contradictory views on the Montado in this way, the farmers protect themselves from a constant inner conflict that would be difficult to deal with on a daily basis.

As described in literature (Schiere et al., 2012; Milestad et al., 2012; Noe and Alroe 2010), the strategy of the farmer is normally to achieve coherence and closure in his/her farm, in the face of the existing context and considering the farm system and the networks he/she is part of. Without being formulated this way, the strategy 
of farmers is often guided by resilience thinking, which is grounded in knowledge and intuition and supports farms survival (Darnhofer 2014; Nuthall 2012). But the central issues here seem to be removed from the farm system and placed on the networks, as if the management strategies were defined by factors which are totally outside the farm. Thus, what our empirical evidence shows is that the focus of farm management goals in the Montado at present is gradually moving from maintaining coherence between internal processes on the farm and reproduction, thus securing long-term resilience, to managing relations with external actors, systems, inputs, revenues and financial partners. In this way, knowledge about the Montado's sensitive balance, passed down from one generation to the next within families and networks of farmers, and establishing grounds for management intuition (Nuthall 2012; Pinto-Correia and Godinho 2013), is set aside. It is not only the present management options which are biased by the strength of external factors, it is also the farmers' comprehensive knowledge foundation which is eroded. The resilience thinking which has made the maintenance of the Montado possible until recently, and which is expressed in farmers' representation of the Montado and its sustainability, is kept merely as a kind of utopia, useless in practice.

An increasingly dramatic result of this process relates to the system's resilience limits: beyond a critical threshold, tree cover regeneration and recovery of the soil becomes impossible and the long-term degradation of the biophysical conditions becomes unavoidable (Schermer et al., 2016; Godinho et al., 2014, 2016). As a result, the future possible use of these former Montado areas is highly uncertain.

The structure of the CAP's 1st Pillar payments schemes, combined with the weakness of the 2 nd Pillar, are central to this process. CAP has accumulated a number of internal contradictions in recent years (Beaufoy 2014), and although the discourse has changed, the practice of policy implementation remains focused on intensive farming systems. Previous literature has showed how the structure of CAP payments applied to livestock production in the Montado is creating instability for farmers' income and affecting management strategies (Godinho et al., 2014, 2016; Fragoso et al., 2011). The fundamental role of institutions and policies in securing or eroding farm systems and their valuable outcomes, besides production, is well known and described in literature (Schermer et al., 2016). And in this case there is a clear impact on the management options taken by farmers, even if these lead to a decrease in the Montado's resilience capacity and a decline in what the same farmers consider to be important values (heritage, forest stability, cork production). What our empirical material also shows is that there is an underlying tension driven by the present policy tools affecting the Montado, which is kept non-explicit in farmers' everyday management practices. In order to cope with this tension, farmers are envisaging their options as external to the farm system and reducing the resilience thinking which was inherent to the internal farm system rationale.

\section{Concluding remarks}

The most powerful public policy as regards farm management in Europe is the CAP. In its current format and the way it has been applied in Portugal, it is driving the management of the Montado system into specialized meat cattle production - thus eroding the complex sustainability foundations which the Montado has maintained until recently and severely affecting its long-term resilience. The decay of the Montado area, recorded every year since the beginning of the nineties, attests to this process. It is also demonstrating that the critical threshold, beyond which radical changes in this system take place and regeneration of the Montado is made impossible, has been exceeded in many places. Farmers retain their knowledge and intuition on the sensitivity of the system, as well as a sense of heritage, which could form the basis for the continued balanced management of this system. Nevertheless, at present they are externalizing the Montado management drivers and pursuing options they defend with short-term economic reasoning. They are not acknowledging their responsibility for the trends registered and the decay of the Montado as a system. They hold up the Montado as an image of the past, or of a desirable future - to be maintained in limited conservation areas, as a kind of nature and cultural reserve. Consequently, they do not search for alternative and adaptive options. The maintenance of the Montado as a forestry system is being reduced to the preservation of small and well-limited patches on each farm. If policy practice and discourse does not move towards a specific approach for Mediterranean silvo-pastoral systems, the preservation of the Montado as we still observe it today is already severely threatened in the short term.

\section{Acknowledgments}

This work was partially funded by the project FCT-PTDC/CSGEO/110944/2009. Carla Azeda holds an FCT doctoral grant (SFRH/BD/94966/2013). This work was also funded by National Funds through the FCT - Foundation for Science and Technology under the Project UID/AGR/00115/2013.

\section{References}

Acácio, V., Holmgren, M., 2012. Pathways for resilience in Mediterranean cork oak land use. systems. Ann. For. Sci. 71, 5-13.

Almeida, M., Guerra, C., Pinto-Correia, T., 2013. Unfolding relations between land cover and farm management: high nature value assessment in complex silvo-Pastoral systems. Geografisk Tidsskrift-Danish J. Geogr. 113 (2), 97-108, http://dx.doi.org/10.1080/00167223.2013.848611, Routledge.

Almeida, M., Azeda, C., Guiomar, N., Pinto-Correi, T., 2015. The effects of grazing management in montado fragmentation and heterogeneity. Agrofor. Syst., http://dx.doi.org/10.1007/s10457-014-9778-2.

Antaki, C., 2008. Discourse analysis and conversation analysis. In: Alasuutari, P. Bickman, L., Brannen, J. (Eds.), The SAGE Handbook of Social Research Methods. Sage, pp. 431-446.

Aronson, J., Santos-Pereira, J., Pausas, J.G., 2009. General introduction. In: Aronson, J., Santos-Pereira, J., Pausas, J.G. (Eds.), Cork Oak Woodlands on the Edge: Ecology, Adaptive Management, and Restoration. Island Press, Washington, DC, pp. $1-10$.

Barroso, F., Pinto-Correia, T., 2014. Land managers ' heterogeneity in mediterranean landscapes - consistencies and contradictions between attitudes and behaviors. J. Landscape Ecol. 7 (1), 45-74 http://mendelu. vedeckecasopisy.cz/publicFiles/00671.pdf.

Beaufoy, G., 2014. Wood pastures and the common agricultural policy. In: Hartel, T., Plieninger, T. (Eds.), European Wood Pastures in Transition. A Socio-Ecological Aproach. Routledge, Oxon, pp. 273-281.

Cochet, Hubert, 2012. The systeme Agraire concept in francophone peasant studies. Geoforum 43 (1), 128-136, http://dx.doi.org/10.1016/j.geoforum.2011. 04.002 (Elsevier Ltd).

Costa, A., Madeira, M., Lima Santos, J., Oliveira, A., 2011. Change and dynamics in mediterranean evergreen oak Woodlands landscapes of Southwestern Iberian Peninsula. Landscape Urban Plann. 102 (3), 164-176, http://dx.doi.org/10. 1016/j.landurbplan.2011.04.002 (Elsevier B.V.).

Darnhofer, I., Gibbon, D., Dedieu, B., 2012. In: Sringer (Ed.), Farming Systems Research into the 21 St Century: The New Dynamic.

Darnhofer, I., 2014. Resilience and why it matters for farm management. Eur. Rev Agric. Econ. 41 (3), 461-484, http://dx.doi.org/10.1093/erae/jbu012.

Ferraz-de-Oliveira, Maria Isabel, Azeda, Carla, Pinto-Correia, Teresa, 2016. Management of montados and dehesas for high nature value: an interdisciplinary pathway. Agrofor. Syst. 90 (1), 1-6, http://dx.doi.org/10.1007/ s10457-016-9900-8 (Springer Netherlands).

Fragoso, R., Marques, C., Lucas, M.R., Martins, M.B., Jorge, R., 2011. The economic effects of common agricultural policy on mediterranean montado/dehesa ecosystem. J. Policy Model. 33 (2), 311-327, http://dx.doi.org/10.1016/j. jpolmod.2010.12.007 (The Society for Policy Modeling).

Godinho, S., Gil, A., Guiomar, N., Neves, N., Pinto-Correia, T., 2014. A remote sensing-Based approach to estimating montado canopy density using the FCD model: a contribution to identifying HNV farmlands in southern Portugal. Agrofor. Syst., http://dx.doi.org/10.1007/s10457-014-9769-3.

Godinho, S., Guiomar, N., Machado, R., Santos, P., Sá-Sousa, P., Fernandes, J.P., Neves, N., Pinto-Correia, T., 2016. Assessment of environment, land management, and spatial variables on recent changes in montado land cover in southern Portugal. Agrofor. Syst. 90 (1), 177-192, http://dx.doi.org/10.1007/ s10457-014-9757-7. 
Guerra, C., Pinto-Correia, T., Metzger, M.J., 2014. Mapping soil erosion prevention using an ecosystem service modeling framework for integrated land management and policy. Ecosystems 17 (5), 878-889, http://dx.doi.org/10. 1007/s10021-014-9766-4.

Guerra, C.A., Metzger, Marc J., Maes, J., Pinto-Correia, T., 2015. Policy impacts on regulating ecosystem services: looking at the implications of 60 years of landscape change on soil erosion prevention in a mediterranean silvo-Pastoral system. Landscape Ecol., http://dx.doi.org/10.1007/s10980-015-0241-1 (Springer Netherlands).

Hermans, F., Kok, K., Beers, P.J., Veldkamp, T., 2012. Assessing sustainability perspectives in rural innovation projects using Q-methodology. Soc. Ruralis 52 (1), 70-91, http://dx.doi.org/10.1111/j.1467-9523.2011.00554.x.

Herzfeld, T., Jongeneel, R., 2012. Why do farmers behave as they do? understanding compliance with rural, agricultural, and food attribute standards. Land Use Policy 29 (1), 250-260, http://dx.doi.org/10.1016/j. landusepol.2011.06.014 (Elsevier Ltd.).

Hyvarinen, M., 2008. Analysing narratives and story telling. In: Alasuutari, P., Bickman, L., Brannen, J. (Eds.), The SAGE Handbook of Social Research Methods. Sage, pp. 447-460.

Liu, Yaolin, Feng, Yuhao, Zhao, Zhe, Zhang, Qianwen, Su, Shiliang, 2016. Socioeconomic Drivers of Forest Loss and Fragmentation: A Comparison between Different Land Use Planning Schemes and Policy Implications. Land Use Policy, 58-68, http://dx.doi.org/10.1016/j.landusepol.2016.01.016 (Elsevier Ltd.).

Milestad, R., Dedieu, B., Darnhofer, I., Bellon, S., 2012. Farms and Farmers Facing change:The Adaptive Approach. In: Springer (Ed.), Farming Systems Research into the 21 st Century: The New Dynamic. , pp. 365-385, http://dx.doi.org/10. 1007/978-94-007-4503-2_16.

Moreno, G., Franca, A., Pinto-Correia, T., Godinho, S., 2014. Multifunctionality and dynamics of silvopastoral systems. Options Mediterr. A 109, 421-436.
Noe, E., Alrøe, H.F., Langvad, A.M.S., 2008. A polyocular framework for research on multifunctional farming and rural development. Soc. Ruralis 48 (1), 1-15, http://dx.doi.org/10.1111/j.1467-9523.2008.00451.x.

Nuthall, P.L., 2012. The intuitive world of farmers - the case of grazing management systems and experts. Agric. Syst. 107, 65-73, http://dx.doi.org/ 10.1016/j.agsy.2011.11.006 (Elsevier Ltd.).

Pinto-Correia, T., Godinho, S., 2013. Agriculture in mediterranean europe: between old and new paradigms. In: Agriculture in Mediterranean Europe: Between Old and New Paradigms, 19:75-90. Research in Rural Sociology and Development. Emerald Group Publishing, Bingley, http://dx.doi.org/10.1108/S10571922(2013)0000019006.

Pinto-Correia, T., Ribeiro, N., Sá-Sousa, P., 2011. Introducing the montado, the cork and holm oak agroforestry system of southern Portugal. Agrofor. Syst. 82 (2), 99-104, http://dx.doi.org/10.1007/s10457-011-9388-1.

Pinto-Correia, T., 1993. Threatened landscape in alentejo: Portugal: the 'Montado' and other 'Agro-Silvo-Pastoral' systems. Landscape Urban Plann. 24, 43-48.

Sales-Baptista, Elvira, D’Abreu, Manuel Cancela, Ferraz-de-Oliveira, Maria Isabel, 2015. Overgrazing in the montado? the need for monitoring grazing pressure at paddock scale. Agroforestry Systems, 57-68, http://dx.doi.org/10.1007/ s10457-014-9785-3, Springer Netherlands.

Schermer, Markus, Darnhofer, Ika, Daugstad, Karoline, Gabillet, Marine, Lavorel, Sandra, Steinbacher, Melanie, 2016. Institutional impacts on the resilience of mountain grasslands: an analysis based on three european case studies. Land Use Policy 52, 382-391, http://dx.doi.org/10.1016/j.landusepol.2015.12.009 (Elsevier Ltd.).

Schiere, J.B., Darnhofer, I., Darnhofer, M., 2012. Dynamics in Farming Systems: Of Changes and Choices.pdf. In: Springer (Ed.), Farming Systems Research into 21th Century: The New Dynamic. , pp. 337-363, http://dx.doi.org/10.1007/ 978-94-007-4503-2_15. 